\title{
Analysis of Physicochemical Transformation (Istiḥālah) Issues in Halal Industry according to Shari'ah Perspective
}

\author{
Mastura Razali 1, Nurhanisah Hadigunawan 2, Rafeah Saidon 3, Nur Farhani Zarmani 4 \\ ${ }^{1}$ Academy Contemporary of Islamic Studies, \\ Universiti Teknologi MARA, Cawangan Pulau Pinang, Kampus Permatang Pauh, 13500 Pulau Pinang, Malaysia \\ ${ }^{2}$ Academy Contemporary of Islamic Studies, Universiti Teknologi MARA, 40450 Shah Alam, Selangor, Malaysia \\ mastura458@uitm.edu.my, nurhanisah@uitm.edu.my, rafeahs@uitm.edu.my,nurfarhani@uitm.edu.my \\ Tel: +60125028419
}

\begin{abstract}
The process of istitālah is applied widely in multiple halal industries. However, Muslim jurist have different opinions about the ruling of istitạlah process Hence, this paper purports to look into the perspective of Shari'ah about some contemporary istilālah issues in the halal industry and its application in Malaysia. Qualitative methodology was adopted by collecting and analyzing the opinions of Islamic jurists relating to the process of istilālah and issues related. The study finds that the opinions by Muslim jurists regarding an istilặlah process that is applied holistically and scientifically can significantly impact the halal status of a product being studied.
\end{abstract}

Keywords: Istihālah; Halal Industry; Halal Issues

eISSN: 2398-4287 @ 2021. The Authors. Published for AMER ABRA cE-Bs by e-International Publishing House, Ltd., UK. This is an open access article under the CC BYNC-ND license (http://creativecommons.org/licenses/by-nc-nd/4.0/). Peer-review under responsibility of AMER (Association of Malaysian Environment-Behaviour Researchers), ABRA (Association of Behavioural Researchers on Asians) and cE-Bs (Centre for Environment-Behaviour Studies), Faculty of Architecture, Planning \& Surveying, Universiti Teknologi MARA, Malaysia.

DOI: https://doi.org/10.21834/ebpj.v6iSI6.3037

\subsection{Introduction}

Cleanliness (taharah) is a highly commendable practise in Islam, and usage of non-permissible materials such as pig, blood and excretion is forbidden because they are filth. Nevertheless, as the effect of the advancement of technologies and globalization, it is found that many products such as food, tableware, and medicine are produced from non-permissible sources. Among them are bone china and surimi products. Bone china is a term used to denote porcelain tableware whose composition comprises animal bone (Salleh et al., 2020)The combination of animal bone will give bone china products the highest production quality compared to ordinary tableware. Demand for Chinese bone products is high, including among Muslim buyers due to their better quality than other ceramic products. Not only that, even in luxury hotels, these products are used to serve food (Salleh \& Subri, 2018)

The passage of time and modern technology in food production has caused concern among contemporary scholars. This is because there have been efforts to mix illegal substances with halal substances in food such as flowing blood that has been modified into powder and then processed into dubious modern food products. Even more worrying when there is a food industry today that uses pig, cow blood and its derivatives such as plasma and red cells as part of food ingredients sold in dry powder form (Kashim, et al., 2017)

Surimi is a paste made from fish meat formed by leaching and was further blended with sugar, polyphosphate, and blood plasma (transglutaminase) (Jabatan Perikanan Malaysia, 2014; Rosa Adrianne, 2015). There are many products containing surimi including

eISSN: 2398-4287 @ 2021. The Authors. Published for AMER ABRA cE-Bs by e-International Publishing House, Ltd., UK. This is an open access article under the CC BYNC-ND license (http://creativecommons.org/licenses/by-nc-nd/4.0/). Peer-review under responsibility of AMER (Association of Malaysian Environment-Behaviour Researchers), ABRA (Association of Behavioural Researchers on Asians) and cE-Bs (Centre for Environment-Behaviour Studies), Faculty of Architecture, Planning \& Surveying, Universiti Teknologi MARA, Malaysia. DOI: https://doi.org/10.21834/ebpj.v6iSI6.3037 
products produced by MARDI research officers from the Food Research and Food Research Center which is Lof Surimi berdaging (Fatihah, 2020).

The main materials used in the production of both products are bone and animal blood, respectively. However, they are not being used conventionally in their original and raw state but have gone through a transformation process that changed their original state, called istihāalah. Istihālah is an alternative purification mechanism to produce a material or a substance that is pure and permissible from sources that are non-permissible and involving natural or non-natural transformation agents through the synthetic process or human intervention (Jamaludin \& Radzi, 2009). It is adopted to determine the certainty of permissibility and non-permissibility status especially relating to the production of Muslim products (Mahaiyadin \& Osman, 2018). Thus, this study purports to explore the opinions of the classical and contemporary Muslim scholars relating to surimi and bone china products that emerged from the process of istihâlah in the halal industry and its application in Malaysia.

\subsection{Literature Review}

\subsection{Concept of Istihạālah}

Conceptually, many definitions of istihālah have been provided by Muslim scholars. Both definitions had similarities in the process of istilah, which refers to the transformation of one substance into another. Alternatively, the concept of figh, which is the transformation of an impure material into a pure material permissible in the eyes of shara' (Nuryani \& Kashim, 2014). Due to that, the implementation of istihāalah can happen through its structure, as shown in Fig. 1 below.

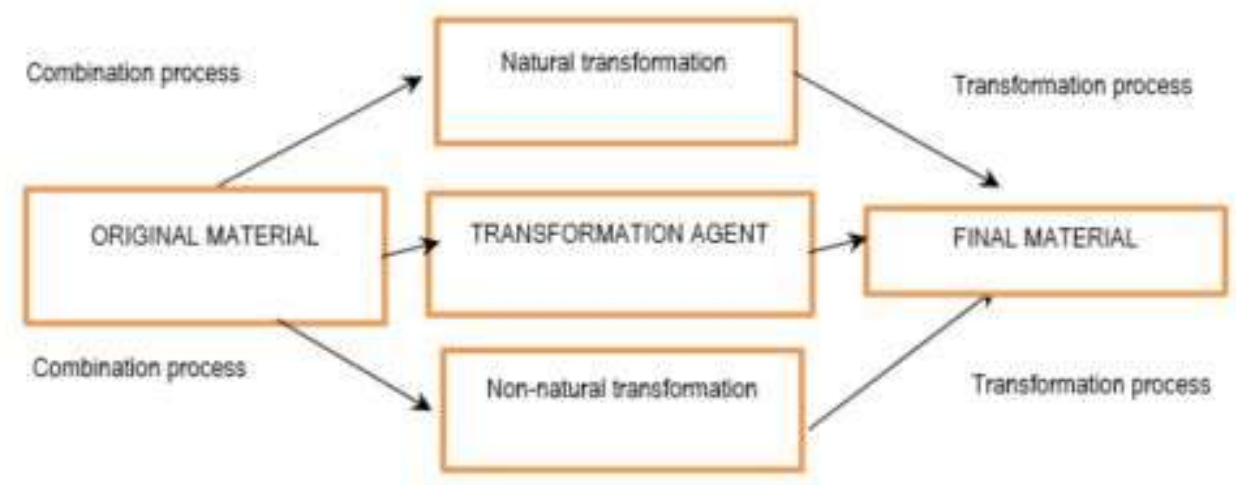

Fig. 1: The Structure of Istihalah

Fig 1 above shows three main elements involved: original material, transformation agent and creation of new material, and complemented by two processes called preliminary and final process. The early process is the process of combination that involves combining original material with an agent of transformation. While the final process or transformation process occurs when the original material (raw material) interacts with the transformation agent either through natural means (temperature, climate, environment) or nonnatural means (enzyme, microbe, chemical). In the process, the combined material will undergo a transformation that results in producing the final material (a new product) (Salleh et al., 2020)

Hence, the state of the final material/new product resulting from the process of istihālah becomes a benchmark in the deliberation of Islamic ruling among Muslim scholars. An in-depth and detailed examination into the original material and agent and the transformation process affects the production of the final material, either accepted or rejected based on Islamic law (Sidek \& Ridzwan, 2017)

Istihālah can be classified into two categories: istihāalah șahịhah (the valid istiḥālah) and istiḥālah fasīdah (the invalid istiḥālah) (Alwi, 2019). For istihālah, șahīhah the final material produced must be transformed into permissible material even though in the process the original material is non-permissible. There are three circumstances where the process can be considered to be istihālah șahịhah. Muslim scholars have accepted istihālah șahihah as conclusive permissibility of the final material that has gone through the process of transformation. While istihāalah fasĩdah occurs in two circumstances in which the resulted final material is categorized as non-permissible. Available here is the formula for each circumstance of istihāalah, as formulated in table 2 below.

Table 2. Formula for Istihāălah Șahihah

\begin{tabular}{llll}
\hline No. & Formula & Description & Example \\
\hline 1$)$ & $\mathrm{H} 1+\mathrm{H} 1=\mathrm{H} 1$ & $\begin{array}{l}\text { Original material }(\mathrm{H} 1)+\text { transformation agent }(\mathrm{H} 1)=\text { final material } \\
(\mathrm{H} 1)\end{array}$ & $\begin{array}{l}\text { Plants + water = cordial } \\
\text { Original material }(\mathrm{H} 2)+\text { transformation agent }(\mathrm{H} 1)=\text { final material } \\
(\mathrm{H} 1)\end{array}$ \\
$\begin{array}{l}\text { Original material }(\mathrm{H} 1)+\text { transformation agent }(\mathrm{H} 2)=\text { final material } \\
(\mathrm{H} 1)\end{array}$ & $\begin{array}{l}\text { Catfish fed with pigs' intestines + quarantine } \\
=\text { clean catfish } \\
\text { Fruit trees + Fertilizer from pigs' excretion = } \\
\text { fruits }\end{array}$ \\
\hline $\begin{array}{ll}* \text { notes: } \mathrm{H} 1 \text { represents the permissible, } \mathrm{H} 2 \text { represents the non-permissible. }\end{array}$
\end{tabular}


Table 2 above shows that istihālah șahịhah can occur in three circumstances. First, it is the combination of permissible original material with permissible transformation agent until the transformation process takes place and produce the permissible final material. For example, in the production of cordial, the original material from the plant is mixed with water as a transformation agent, and the process of transformation turns it into permissible cordial. The second circumstance involves non-permissible original material that has reacted to a combination with permissible transformation agent. Thus, a transformation process occurred, resulting in the final material that is permissible. For instance, al-jalallah animals such as catfish fed with pig's intestines that are originally non-permissible but have gone through a quarantine process that is considered a transformation agent have resulted in the transformation of the catfish to be legally permissible. The final circumstance that falls under istihālah is when the original material is combined with a non-permissible transformation agent but produces a permissible final material. Among the examples refers are; fruit trees whose nature is legally permissible but were then fertilized with pig's excretion, a non-permissible transformation agent, resulting in the new product in the form of a legally permissible frument. In this situation, the pig's excretion acts only as an external transformation agent that makes the soil fertile and produces good and high-quality fruits (Aizat, 2013).

\begin{tabular}{llll} 
& & \multicolumn{2}{c}{ Table 3. Formula for Istihāalah Fasidah } \\
\hline No. & Formula & Description & Example \\
\hline 1$)$ & $\mathrm{H} 1+\mathrm{H} 1=\mathrm{H} 2$ & $\begin{array}{l}\text { Original material }(\mathrm{H} 1)+\text { transformation agent }(\mathrm{H} 1)=\text { final material } \\
(\mathrm{H} 2)\end{array}$ & $\begin{array}{l}\text { Original material }(\mathrm{H} 1)+\text { transformation agent }(\mathrm{H} 2)=\text { final material } \\
(\mathrm{H} 2)\end{array}$ \\
& $\mathrm{H} 1+\mathrm{H} 2=\mathrm{H} 2$ & ${ }^{*} \mathrm{H} 1$ represents the permissibles, $\mathrm{H} 2$ represents the non-permissibles
\end{tabular}

Table 3 above shows that the process of istihālah fasīdah occurs under two circumstances. The first circumstance is a combination of permissible original material with a permissible transformation agent. However, its final material formed from the transformation is nonpermissible. For example, the grapes as original material is permissible, but after going through the process of fermentation, which is considered a permissible transformation agent, the final material produced is the wine, which is non-permissible. The second circumstance occurs when a permissible original material is mixed with a non-permissible transformation agent, thus producing a non-permissible final material. For instance, the dough for cake-baking is originally permissible, but then it was mixed with a non-permissible transformation agent, which is wine, to enhance the physical appearance of the cake, resulting in the cake being categorized as non-permissible final material. Due to that, to determine whether the process that occurred was an istihāalah șaḥihhah or istihạalah fasīdah requires a detailed deliberation because the process eventually leaves an impact on the status of permissibility or non-permissibility of the final material (Jamaludin \& Radzi, 2009).

\subsection{Bone China}

Bone china is a type of soft porcelain earthenware produced from a combination of animal bone ash (bone ash), red or white minerals that contain silicate (feldspar) and also white clay (kaolin) (Salleh et al., 2020). Bone china has some special features compared to other porcelains (hard-paste porcelain and soft-paste porcelain), such as low usage of fuel, formation of a whiter and cleaner product that is durable and translucent (Huang et al., 2021). However, some improvements have been made by Josiah Spode circa 1789 to 1793 by leveraging the formulation of porcelain materials from China with the addition of cattle bone ash resulting in the production of bone china (Zainal \& Hamdzun, 2014), which has been categorized as exclusive porcelain and having high quality because the price is higher compared to other porcelain ceramic products.

Globally, bone china is produced from animal bone sourced from cattle, goats and pigs. This is because bones from these three kinds of animals can be found in large quantities. However, according to a study made by Salleh et al. (2020) it is found that all international manufacturers (or producers) of bone china used cattle bone in its production, compared to other animal's. Because many bone china products are made in Japan, United Kingdom, and China, the possibility of using bones from unslaughtered animals is high based on the cultural and religious practices of its majority who are not professing Islam.

Thus, ambiguity arises among the Muslims regarding the permissibility status of pig bone and unslaughtered animal bone (categorized as carcass and filth according to the majority of the Muslim scholars from Maliki, Shafi'i and Hanbali schools) although it has gone through the process of istihạalah.

\subsection{Surimi}

Surimi is a Japanese word that brought the meaning of fish paste formed by leaching and was then blended with sugar and polyphosphate. The industrial processing of surimi was introduced into Malaysia during the early ' 80 s. Since then, the processor has known the advantages of using frozen surimi as part of half-processed raw material. Using surimi as raw material is more convenient in handling, transportation, storage, preparation, quality control, and more stable supply and prices when compared with using fresh fish (Jabatan Perikanan Malaysia, 2014). Surimi is permissible, but they tend to add blood plasma into surimi products in the current food industry. It is estimated that about $30 \%$ of the food industry uses animal's blood in the manufacturing of their products. This is because blood plasma has high solubility and the ability to emulsify and form a strong gel and low viscosity. Otherwise, it can add texture to processed food products such as meat and fish (Sahilah et al., 2016). This bind is traditionally used in meat products to avoid texture and sensorial changes as an after-effect of processing (Malav et al., 2018). 


\subsection{Methodology}

This study applied a qualitative method based on content analysis techniques to obtain data. Content analysis is research covering an extensive range of fields, and its application is widely used (Rashidi et al., 2014). (Bengtsson, 2016) defines content analysis as a research technique that concludes and validates the text resulting from the assessment and analysis. This study has reviewed comprehensive article related to process of istihāalah, bone china and surimi. In addition, the books are also used to analyze the views of Islamic scholars on the ruling of istihālah. Islamic institution websites such as JAKIM have been referred to get information on contemporary fatwa on bone china and surimi. All these data are conceptually analyzed to study the application and Islamic ruling on bone china and surimi. The limitations of this study focus on istihālah in bone china and surimi products This study conduct qualitative methodology in analyzing the opinion of Islamic scholar on the ruling of istihalah.

\subsection{Findings and Discussion}

\subsection{The Application of Istihālah in Bone China Product}

In the context of the production of bone china, the non-permissible animal bone is not used conventionally in its original and raw form, but it has gone through the process of transformation from its original state. The application of istihālah in the production of bone china is illustrated in the following Fig. 2:

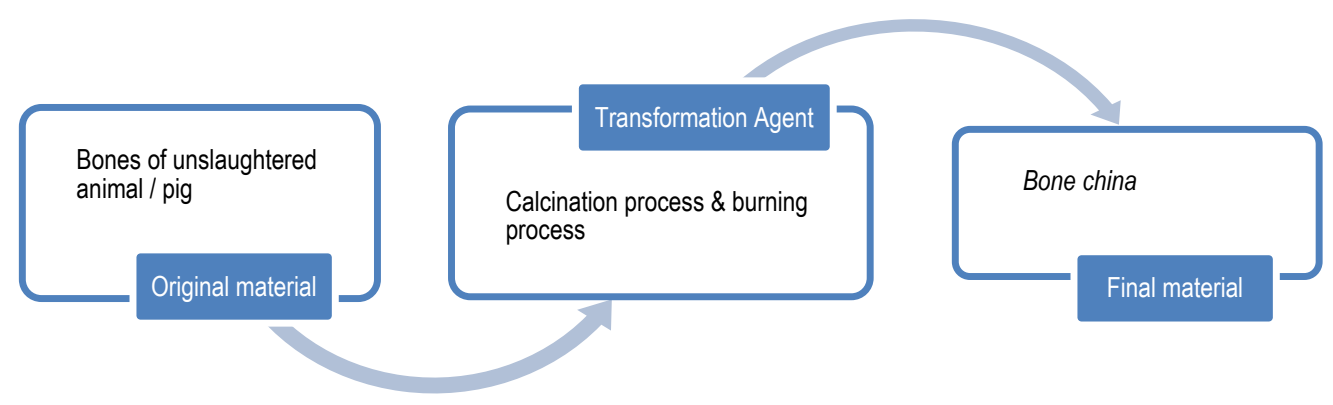

Fig. 2: The process of Istihālah in Bone China Product

The raw bone (pig's or other permissible unslaughtered animals') are initially boiled to remove the residue of meat, fat and blood that are still attached to the bones and remain thereof. Then, it will be burnt at the temperature of $10000 \mathrm{C}$, thrice and non-stop, before it is grounded and filtered to produce ash powder of the bone finally. The resulting ash powder of the bones exists in the form of oxides and calcium phosphates. Then, the bone ash is blended with kaolin and feldspar to form a final material called bone china body (Salleh \& Irwan, 2018) These processes transformed the properties of the original material that has been used, either raw bone sourced from cattle, pig or another non-permissible animal, to become permissible because there is an occurrence of transformation from its non-permissible essence and physical form to become a new essence and physical form which is permissible and pure.

\subsection{The Islamic Ruling on Bone China Sourced from Animal Bone}

The process shows that animal bone whether the animals are unslaughtered or pigs that have seen complete transformation according to Hanafi and Maliki schools. The final product finds the element of bone (ash bone) that is the primary material in the production of bone. China products have been transformed into carbon elements after they went through calcination and some other burning processes to produce bone china products that passed the quality control standard for market consumption. Based on this situation, istihālah șahīhah has been applied in the production of bone china products. As a result, all the products are labelled as pure and allowed to be used by Muslim consumers because no 'illah has made it filthy.

However, if it is considered from the perspective of Shafi'i and Hanbali schools, the filthiness of the bone remains in bone china products, and the filth as its properties will not disappear. Based on this circumstance, the transformation process is considered to be never taking place, and the filthiness remains as its properties, and it does not go through any transformation process at all. This is in agreement with their views on the process of istihālah itself, that is, a process that originates from a non-permissible source remains to be filth although it has transformed from its original form. It means that filth does not become pure even though its properties, elements and nature changed (al-Ghananim, 2008).

The differing opinions of Islamic scholars from different schools of Islamic law regarding istihālah affect the process of issuing a current legal opinion on the legal status of bone china. Some countries allow this product, while others prohibit it. Among religious authorities that allow for the usage of products from animal bones such as Singapore, South Africa and the United States. They stated that because the nature of the bones has changed, and bone china has been complexly combined with other materials, tableware made from bone china can be used to prepare food, and they are not filthy (Man, 2014).

While the Mufti Department of Malaysia and Brunei has given an Islamic judgement on the non-permissibility of bone in China, whether it is created with sources from pigs or lawful animals that are not slain in an Islamic manner. For example, the 99th Muzakarah Fatwa Committee of the National Council for Islamic Religious Affairs Malaysia, decided that: ".... according to the Shafi'i school, the filthy nature 
of the pig remains in the bone china product and the filthy nature will not disappear because the process of istihālah is considered not to be effective." If it is permitted, then it will give more space to other products based on animal sources which are not permissible according to shari'ah to become spreading" (Jabatan Kemajuan Islam Malaysia, 2015).

Hence it can be concluded in the context of Malaysia that using bone china is not permissible based on the strong bind with the Shafi'i school in Malaysia. It is also closely related to the sensitivity of the Muslim society concerning the issues of pig which has a great influence on the context of 'urf among the Malays, other than the needs of the society towards the product itself is not reaching the level of necessity (darurah) (Hammad, 2004).The legal maxim suitable to be used in this case, meaning that an ambiguous matter must be avoided, is feared to be more inclined towards non-permissibility. Hence, the Muslims are encouraged to be cautious (ihțiyāt) regarding the usage and formation of products whose permissibility and non-permissibility for fear of falling into ambiguous matters (shubhah).

\subsection{The Application of istihālah in Blood Plasma-Based Surimi Products}

The process of istihālah has occurred in the formation of the product because it involves the structure of istihālah such as original material, transformation agent and final material, like fish-balls. The application of istihālah in the production of surimi is illustrated in the following Fig. 3:

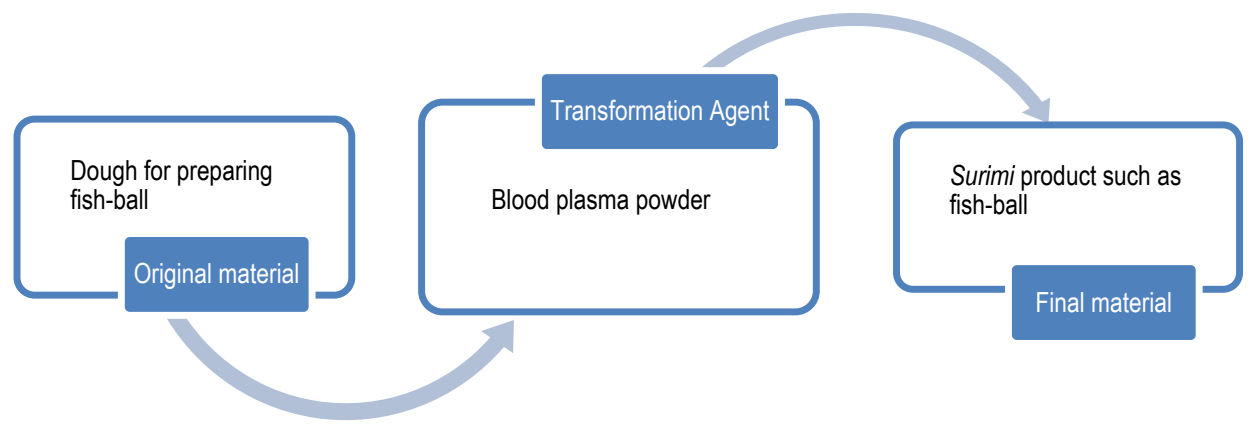

Fig. 3: The Process of Istihāalah in Surimi Products

Surimi is produced from bits of fish flesh. However, due to the low viscosity level, the food industry operators have blended it with thickening agents based on blood plasma powder from different sources, usually made from cattle's or pig's blood. Blood plasma is the colourless liquid that is part of the blood and forms the blood itself. The centrifugation method separates blood from blood, which filters out the part that gives blood its red colour (Devadason et al., 2010). After the separation, the plasma is dried with a dedicated spray drier tool until it turns powdery. The powder is used to improve the quality of surimi products.

\subsection{The Status of Islamic Ruling Regarding Blood Plasma-Based Surimi}

According to Hanafi school and Maliki school (Ibn al-Juzayr, 1991) that classify this process as istihālah șahịhah if its original state has transformed into a new product. According to al-Qaradawi (1993), the usage of part of blood elements such as enzyme, plasma, white or red blood cells is allowed. Among the arguments in support of this opinion was found in surah al-An'am verse 145 where 'illah of its nonpermissibility is the 'flowing blood', but its characteristic does not apply to blood plasma powder that has gone through a complete process of istihālah where the identity of blood has changed or transformed either by its appearance and its essence (Kashim, et al., 2017).

Meanwhile, the second opinion from the Shafi'l (al-Nawawi, 2010) and Hanbali (ibn al-Qudamah, 1979) schools categorized it as istihālah fasīdah because the nature of blood as filth remains in the surimi product formed. This opinion applies several methodologies as its arguments such as "When there is a mixture between the permissible and non-permissible, the non-permissible is given more weight than the permissible" and the methodology of 'sad al-dhara'i', that is of preventing harm in the production of food products. They also argue that it is a precautionary measure to avoid involvement with the non-permissible (Ismail, 2010).

In this case, no decision during muzakarah fatwa was mentioned specifically on blood plasma in a food product. However, most contemporary Muslim scholars such as (al-Qaradawi, 1993; al-Rabi', 2007; al-Zuhayli, 1997; Hawwa, 1994; Salihin, 1991) opined that using blood plasma in food products are allowed if the complete process of istihālah has occurred. However, the use must be minimum only to avoid the risk of damaging the surimi products (Kashim et al., 2015).

In Malaysia, initially, the decision of the 2nd Muzakarah Fatwa Committee stated that the processing of food that mixed with filth such as blood of cattle, pig and other animals are allowed and permissible. However, the latest legal opinions are not discussing these issues in a specific manner. Hence, many researchers are more inclined towards the legal opinions of the Hanafi and Maliki schools that view istihâalah in the larger and wider context. This is because the advancement of current technologies can prove whether the product processing has occurred at the level of istihāālah șahīhah is valid or not (Kashim, 2017).

\subsection{Conclusion}

The production of bone china and surimi products demonstrated that ambiguous materials such as bone and animal blood are involved in their manufacturing. Although the concept of istihālah has been applied to ensure the permissibility and purity of the two products, classical 
and contemporary Muslim scholars differ in their opinions regarding the conclusive status of its permissibility. Nonetheless, we as a society must stay alert and be sensitive about buying and using these daily consumer products, especially those that involve food intake, because it is feared that the permissible material may become contaminated by the non-permissible material, as well as the possibility of the products not undergoing the right process of istihāalah.

\subsection{Contribution/ Originality}

This study is one of the very few studies which investigated the concept of istihālah on bone china dan surimi product from the shariah perspective. The main contribution of this paper is finding that a transformation of filthy or haram materials become a new essence and physical determining the permissibility status of a product.

\section{References}

Aizat, M.J. (2013). Istihalah Konsep dan Aplikasi. Serdang: Universiti Putra Malaysia.

Al-'Ayid, A., et al. (t.t.). Mu'jam al-'Arabi al-Asasi. Tunnis: al-Munazzamah al-'Arabiyah Li al-Tarbiyyah wa al-Thaqafah wa al-'Ulum.

Al-Ghananim, Q. 'Izzat. (2008). al-Istihalah wa Ahkamuha fi al-Fiqh al-Islami. 'Amman: Dar al-Nafa'is.

Al-Nawawi, M. D. I. S. (2010). Al-Majmu'. Kaherah: Dar al-Hadith.

Al-Qaradawi, Y. (1993). Fatawa al-Mu'asarah (2nd ed.). al-Qahirah: Dār al-Wafā'.

Al-Rabi, W. K. (2007). Ahkam al-At'imah fi al-Figh al-Islami. Beyrut: Dar al-Nafais.

Al-Zuhayli, W. M. (1997). al-Fiqh al-Islami wa Adillatuh. Damsyik: Dar al-Fikr.

Alwi, Z. (2019). Halal Analysis Principle for Food and Pharmaceutical: A Case Study of Gelatin. International Conference on Islamic Studies (AICIS 2019).

Bengtsson, M. (2016). How to Plan and Perform A Qualitative Study Using Content Analysis. NursingPlus Open, 2, 8-14.

Devadason, I. P., Anjaneyulu, A. S. R., \& Babji, Y. (2010). Effect of Different Binders on the Physico-Chemical, Textural, Histological, and Sensory Qualities of RetortPouched Buffalo Meat Nuggets. Journal of Food Science, 75(1), 31-35.

Hammad, N. (2004). al-Mawad al-Muharramah wa al-Naiasah fi al- Ghiza' wa al - Dawa' bayna al Nazariyyah wa al-Tatbiq. Damsyik: Dar al-Qalam.

Hawwa, S. (1994). al-Asas fi al-Sunnah wa Fiqhiha. Mesir: Dar al-Salam.

Huang, Z. G., Yi, H. Y., Wang, T., An, L. Y., \& Zhao, X. Bin. (2021). Determination of Ca3(PO4)2 in Bone China by Microwave Digestion-ICP-AES. E3S Web ofConferences, $245,1-6$.

Ibn al-Juzayr, M. A. (1991). al-Qawanin al- Fiqhiyyah. Beyrut: Dar al-Arqam.

Ibn al-Qudamah, 'Abd Allah ibn Ahmad. (1979). Al-Mughni fi Fiqh Imam al-Sunnah Ahmad ibn Hanbal. Beyrut: Dar Kutub al- 'Ilmiyyah.

Ismail, M. S. (2010). Istihalah Sebagai Kaedah Penentuan Hukum Makanan: Analisis Terhadap Isu Makanan Diubahsuai Genetik. In L. Amin \& A. . Samian (Eds.),Permasalahan Etika dalam Bioteknologi (pp. 103-110). Bangi: Institut Alam dan Tamadun Melayu.

Jabatan Kemajuan Islam. (2015). Kompilasi Pamdangan Hukum Muzakarah Jawatankuasa Fatwa Majlis Kebangsaan Bagi Hal Ehwal Ugama Islam Malaysia. Putrajaya:JAKIM Bahagian Pengurusan Fatwa.

Jabatan Perikanan Malaysia. (2014). Kementerian Pertanian dan Industri Asas Tani. https://www.dof.gov.my/index.php/pages/view/144

Jamaludin, M. ., \& Radzi, C. W. J. W. M. (2009). Teori Istihalah Menurut Perspektif Islam dan Sains: Aplikasi Terhadap Beberapa Penghasilan Produk Makanan. JurnalSyariah, 17(1), 169-194.

Kashim, M., M., Hasim, N. A., Othaman, R., Yahaya, M. Z., Khalid, R., Samsudin, M. A., \& DM, M. Z. (2017). Plasma Darah dalam Makanan daripada Perspektif Islam danSains. Sains Malaysiana, 46(10), 1779-1787.

Kashim, M. I. A. M., Majid, L. A., Adnan, A. H. M., Husni, A. B. M., Nasohah, Z., Samsudin, M. A., \& Yahaya, M. Z. (2015). Principles Regarding the Use of Haram(Forbidden) Sources in Food Processing: A Critical Islamic Analysis. Asian Social Science, 11(22), 17-25.

Kashim, M. M. (2017). Istihalah dan Kesannya Kepada Makanan Menurut. Journal of Social Sciences and Humanities, 12(2), 102-111.

M. Salleh, M. M., \& M. Subri, I. (2018). Fatwa Analysis on Bone China Products and Its Halal Solution. Ulum Islamiyyah, 23(November 2017), 53-66.

Mahaiyadin, M. H., \& Osman, M. R. (2018). Kesan Penerimaan Aplikasi Istihalah Terhadap Hukum Produk yang Mengandungi Derivatif Muharramat. Journal of FatwaManagement and Research, 10(1), 101-119.

Malav, O., R, B., KS, V., HS, S., N, M., P, K., \& RV, W. (2018). Safe Disposal of Slaughter House Wastes. Approaches in Poultry, Dairy \& Veterinary Sciences, 2(4), 1-3. 
Man, S. (2014). Contemporary ljtihad on Issues of Istihalah: A Comparative Study Between Fatwas by Middle East Jurists and Malaysian National Fatwa Council.International Conference of Global Islamic Studies 2014

Nuryani, A., \& Kashim, M. M. I. A. (2014). Istihalah dalam Pandangan Islam. Fikiran Masyarakat, 2(1), 19-27.

Pauzi, N., \& Man, S. (2015). Analisis Fatwa-Fatwa Bone China daripada Perspektif Hukum Islam. Journal of Fatwa Management and Research, 5, 55-79.

Rashidi, M. ., Ara Begum, R., Mokhtar, M., \& Pereira, J. J. (2014). Pelaksanaan Analisis Kandungan Sebagai Metodologi Kajian bagi Mengenalpasti Kriteria PembinaanLestari. Advanced Research Design, 1(1), 18-27.

Rosa Adrianne, A. (2015). Ramuan Kritikal Dalam Produk Surimi . http://www.myhealth.gov.my/ramuan-kritikal-dalam-produk-surimi/

S.Fatihah, A. (2020). MARDI hasilkan tiga produk inovasi makanan baharu | Sinar Harian. Sinar Harian . https://m.sinarharian.com.my/mobile-article?articleid=140187

Sahilah, A. M., Liyana, L. M. N. A. S., Aminah, A., \& Mohd Khan, A. (2016). Halal Authentication in Malaysia Context: Potential Adulteration of Nonhalal Ingredients in Meatballs and Surimi Products. International Food Research Journa, 23(5), 1832-1838.

Salihin, A. al-M. M. (1991). Ahkam al-Najasat fi Fiqh al-Islami. Jeddah: Dar al-Majma'.

Salleh, M. M. M., Subri, I. M., Deuraseh, N., Rahman, S. A., Mustafa, S. M., \& Jamaludin, M. A. (2020). An Analysis on the Use of Animal Bones in Water Filte Products from the Halal Perspective: Hijrah Water as Sample. Ulum Islamiyyah, 30, 43-60.

Salleh, M. M. S., \& Irwan, M. S. (2018). Fatwa Analysis on Bone China Products and Its Halal Solution. Ulum Islamiyyah, $23,53-66$.

Tuan Sidek, T. M., \& Ridzwan, A. (2017). Aplikasi al-Istihalah dalam Industri Halal Semasa Menurut Perspektif Maqasid al-Shariah. International Journal of Humanities Technology and Civilization, 2(1), 1-9.

Zainal, Z., \& Hamdzun, H. (2014). Characterisation of Local Bone Ash for Bone China Production. Jurnal Teknologi, 66(1), 25-34. 